\title{
Isolation of Staphylococcus epidermidis, Bacillus cereus and Pseudomonas stutzeri from diseased European sea bass (Dicentrarchus labrax) for the first time in Egypt
}

\author{
Ibrahim M. Aboyadak ${ }^{1}$; ;ader M. Sabry ${ }^{1}$ Nadia G. Ali $^{1}$; and \\ Heba S. El-Sayed ${ }^{2}$
}

1- Fish Disease Lab, Aquaculture Division, National Institute of Oceanography and Fishery (NIOF), Egypt.

2- Fish Reproduction Lab (Marine hatchery), Aquaculture Division, National Institute of Oceanography and Fishery (NIOF), Egypt.

*Corresponding author: Email: i.aboyadak@gmail.com.

\begin{abstract}
During this study, $20 \%$ mortality was recorded in Dicentrarchus labrax brood stock in marine hatchery of National Institute of Oceanography and Fishery at Alexandria province. Observed clinical signs were decrease appetite, off-food, skin ulcerations and tail erosions. The main post mortem lesion was enlarged liver with presence of hemorrhagic foci. Seven bacterial isolates were recovered by initial isolation on typtic soy agar media from topical lesions (skin, musculature and tail) and from internal organs (heart, liver, spleen and posterior kidney). No growth was detected on specific media including Rimler-Shotts, Pseudomonas selective agar, Thiosulfate Citrate Bile Salts Sucrose agar and Edwards media that indicate absence of major fish pathogens. Identification of the causative agents was performed using VITEK 2 automated biochemical identification system. Four Staphylococcus epidermidis, two Bacillus cereus and one Pseudomonas stutzeri isolates were identified as the causative agents responsible for mortalities in diseased Dicentrarchus labrax. Stress factors induced by hatchery conditions could be the predisposing caused of such infection.
\end{abstract}

Keywords: European sea bass, Dicentrarchus labrax, VITEK 2, Staphylococcus epidermidis, Pseudomonas stutzeri, Bacillus cereus.

\section{INTRODUCTION}

European sea bass is considered one of the important marine cultured fish, especially with declining fisheries production. Egypt produces about 15167 ton of cultured European sea bass (GFARD, 2016) and has been ranked as the fifth producer that represent $4 \%$ of total Mediterranean aquaculture of this species (Vázquez and Muñoz-Cueto, 2015).

The most important problem facing expansion in marine aquaculture in Egypt is severe shortage of seed production, decreased hatchery numbers and brood stock mortalities that make the problem more prominent.

Bacterial diseases are considered one of the major causes of economic losses affecting marine culture (Anderson and Conroy, 1970), and are the biggest challenge regarding the European sea bass (Dicentrarchus labrax) Mediterranean aquaculture (Toranzo et al., 2005). Aeromonas spp., Bacillus spp., Flavobacterium spp., Photobacterium, Pseudomonas spp., Staph. epidermidis and Vibrio spp. are the most common bacteria pathogens affecting farmed European sea bass in Greece (Yiagnisis and Athanassopoulou, 2011).Anorexia, lethargies, disorientation, abdominal swelling and external haemorrhages in the head, eyes, skin, gills and at the bases of the fins as 
well as skin ulcers are the most common clinical signs. The main post-mortem lesions include visceral petechiation, pale liver, kidneys, and enlarged spleen (Yiagnisis and Athanassopoulou, 2011).

The VITEK 2 is an automated microbial identification system that provides highly accurate and reproducible results. VITEK 2 system is also a rapid and reliable method for pathogens identification. It has advantage over PCR, PCR need to suspect the tested bacterial strain and use its specific primer and so its results are either positive or negative, while VITEK 2 system is only need to know the tested bacteria is either gram positive or negative.

This study has been conducted to determine the direct cause of mortalities affecting the European sea bass brood stock.

\section{MATERIALS AND METHODS}

\section{Study area:}

Samples were taken from the Marine Hatchery of National Institute of Oceanography and Fishery atAlexandria governorate north Egypt. The affected hatchery complain brood stock mortality reached $20 \%$ between January and March 2016.

\section{Samples:}

Five live moribund fish suffered fromskin ulceration and haemorrhages were collected. Each fish was ranged between 1100 and $1500 \mathrm{~g}$ in body weight. Each fish sample was packed alive in a separate stile labeled plastic bag and transported in ice box to Fish Disease Lab, for isolation of the causative agents.

\section{Clinical examination:}

The clinical examination was performed according to the method described by Noga (2010).

\section{Post mortem examination:}

The post mortem examination was performed according to the method described by Heil (2009).

\section{Isolation and identification of the causative agent:}

Under complete aseptic condition a small pieces of tissues from heart, liver, spleen and posterior kidney were taken from each fish to a test tube containing $10 \mathrm{ml}$ sterile peptone water, after that the sample was homogenized at $3000 \mathrm{rpm}$ for $1 \mathrm{~min}$ using homogenizer pro ${ }^{\circledR}$ USA. Test tubes were centrifuged at $1000 \mathrm{rpm}$ for $30 \mathrm{sec}$ and one $\mathrm{ml}$ from supernatant was added to another test tube containing sterile tryptic soy broth and incubated for $24 \mathrm{~h}$ at $33^{\circ} \mathrm{C}$.

Another sample from the external lesions in the skin, musculature and or tail, were taken using sterile swabs after disinfection of affected area with $70 \%$ ethyl alcohol to avoid contamination from bond water.After that swabs from skin lesion was taken to sterile tryptic soy broth tubesand incubated for $24 \mathrm{~h}$ at $33{ }^{\circ} \mathrm{C}$.

Rimler-Shottsmedia with Ampicillin selective supplement $5 \mathrm{mg} /$ litter (HiMedia), Pseudomonas selective agar with CFC selective supplement (LabM), Thiosulfate CitrateBile Salts Sucrose (TCBS) agar media (Oxoid), Edwards media (Oxoid) and Tryptic soy agar (Oxoid) were streaked from each sample then incubated at $33^{\circ} \mathrm{C}$ for $24 \mathrm{~h}$.

\section{VITEK 2 system identification for recovered isolates:}

\section{Gram staining procedures:}

Gram stain procedures were performed according to the method described by Collins et al. (2004). 


\section{VITEK 2 system protocol:}

\section{For Gram positive and Gram negative recovered isolates:}

Few morphology similar colonies were picked up from tryptic soy agar plate, then dissolved in sterile test tube contain $3 \mathrm{ml}$ of $0.5 \% \mathrm{NaCl}$ saline. The optical density of the solution was tested using Densi Chek Pluscalibrator and adjusted to 0.6 McFarland standards. In the VITEK 2 apparatus Gram positive ID card (GP) was set in the cassette with the suspension test tube. Cards were then inoculated automatically with microorganism suspensions using an integrated vacuum apparatus. The software of the system was logged for data entry and starting the automated pathogen identification process according to manufactures instructions.

\section{For Bacillus isolates:}

The same as in Gram positive isolate except that the optical density of the solution was adjusted to $2 \mathrm{McFarland}$ standard and using Gram Positive Bacillaceae ID card (PCL).

\section{RESULTS AND DISCUSSION}

Bacterial fish diseases represent the major danger facing aquaculture causing severe economic losses, either direct including fish mortality or indirect including costs of treatment (Aboyadak, 2016).

Clinical examination of the diseased Dicentrarchus labrax revealed loss of appetite and off-food, sluggish movement with absence of scape reflex, fish present near bond bottom and before death float in inverted position. Skin ulcerations with presence of hemorrhages, pelvic fin and tail hemorrhage and erosions were also observed (Plates A $1 \& 2 \& 3$ ). The main gross internal lesions of diseased fish were enlarged congested liver with the presence of hemorrhagic foci (Plate A4). Similar clinical signs and post mortem lesions were recorded by Kusuda and Sugiyama (1981), Yiagnisis and Athanassopoulou (2011) and Varvarigos (2016) in Red Sea bream (Chrysophrys major) and in Dicentrarchus labrax fryandadult fish naturally infected with Staphylococcus epidermidis. Parallel to our recorded clinical signs Goodwin et al. (1994) and Chandra et al. (2015) also, recorded presence of skin ulcers and dermatitis in channel catfish and stinging catfish, Heteropneustes fossilis naturally infected with Bacillus mycoides and Bacillus cereus respectively. Sariati, et al. (2015) recorded the presence of petechial hemorrhage on the skin of the catfish and detached scales with hemorrhagic ulcers of tilapia naturally infected with Pseudomonas stutzeri in Indonesia. The recorded clinical signs and post mortem lesions are mainly attributed to both colonization and multiplication of isolated bacteria and the defense mechanism of fish against it by induction of inflammatory response.

All recovered bacterial isolates did not grow on any of specific media including Rimler-Shotts media with Ampicillin selective supplement, Pseudomonas selective agar and Thiosulfate Citrate Bile Salts Sucrose (TCBS) agar media and Edwards media, except Staphylococcus epidermidis that grown on Rimler-Shotts media giving green colonies (Plat A5).Staphylococcus epidermidis may be resistant to Ampicillin that explain its growth on Rimler-Shotts. The isolated bacteria did not grow on mentioned media because they are selective media contain inhibitor for other bacterial species.This indicating absence of major famous fish pathogens including Aeromonas spp., Pseudomonas spp., Vibrio spp. and Streptococcus spp.

On tryptic soy agar Staphylococcus epidermidis has grown producing white pin headed colonies about $1 \mathrm{~mm}$ in diameter (Plat B1), which is identical to that described 
by Huang et al. (1999). Bacillus cereus haslarge, white spherical colonies with dull surface and undulate margins (4-5 mm in diameter, Plate B2), which is agree with Buller (2004). Pseudomonas stutzeri grows producing white to creamy colonies; about $2-3 \mathrm{~mm}$ in diameter (Plate B3) that partially agrees with Sariati et al. (2015).

Gram stain of Staphylococcus epidermidis revealed the presence of gram positive cocci, found as single, pairs, short chain and irregular clusters of cells (Plat B4), that is nearly similar to that recorded by Austin and Austin (2012).Bacillus cereusis present as gram positive long bacilli; single, pairs and chains. It has centrally located endospore (Plate B5) that was recorded also by PHE (2015). Pseudomonas stutzeri appeared as gram negative short bacilli, present single or in pairs (Plate B 6), and this agrees with Buller (2004) description.

VITEK2 is considered advanced automated biochemical identification system. Four Staphylococcus epidermidis isolates were identified by VITEK2 system with98 $\%$ probability; analysis time was 7 hours. The biochemical details are mentioned in (Table 1).

Table 1: Biochemical characters of Staphylococcus epidermidis identified by VITEK 2 system, isolated from Dicentrarchus labrax.

\begin{tabular}{|c|c|c|c|}
\hline Well N. & Biochemical reaction & Appreciation & Results \\
\hline 2 & D-AMYGDALIN & AMY & - \\
\hline 4 & PHOSPHATIDYLINOSITOL HOSPHOLIPASE C & PIPLC & - \\
\hline 5 & D-XYLOSE & $\mathrm{dXYL}$ & - \\
\hline 8 & ARGININE DIHYDROLASE 1 & ADHl & + \\
\hline 9 & BETA-GALACTOSIDASE & BGAL & - \\
\hline 11 & ALPHA-GLUCOSIDASE & AGLU & - \\
\hline 13 & Ala-Phe-Pro ARYLAMIDASE & APPA & - \\
\hline 14 & CYCLODEXTRIN & CDEX & - \\
\hline 15 & L-Aspartate ARYLAMIDASE & AspA & - \\
\hline 16 & BETA GALACTOPYRANOSIDASE & BGAR & - \\
\hline 17 & ALPHA-MANNOSIDASE & AMAN & - \\
\hline 19 & PHOSPHATASE & PHOS & - \\
\hline 20 & Leucine ARYI-AMIDASE & LeuA & - \\
\hline 23 & L-Proline ARYLAMIDASE & ProA & - \\
\hline 24 & BETA GLUCURONIDASE & BGURr & - \\
\hline 25 & ALPHA-GALACTOSIDASE & AGAL & - \\
\hline 26 & L-Pyrrolidonyl-ARYLAMIDASE & PyrA & - \\
\hline 27 & BETA-GLUCURONIDASE & BGUR & - \\
\hline 28 & Alanine ARYLAMIDASE & AlaA & - \\
\hline 29 & Tyrosine ARYLAMIDASE & TyrA & - \\
\hline 30 & D-SORBITOL & $\mathrm{dSOR}$ & - \\
\hline 31 & UREASE & URE & + \\
\hline 32 & POLYMYXIN B RESISTANCE & POLYB & - \\
\hline 37 & D-GALACTOSE & dGAL & - \\
\hline 38 & D-RIBOSE & dRIB & - \\
\hline 39 & L-LACTATE alkalinization & ILATK & + \\
\hline 42 & LACTOSE & LAC & + \\
\hline 44 & N-ACETYL-D-GLUCOSAMINE & NAG & - \\
\hline 45 & D-MALTOSE & dMAL & + \\
\hline 46 & BACITRACIN RESISTANCE & BACI & + \\
\hline 47 & NOVOBIOCIN RESISTANCE & NOVO & - \\
\hline 50 & GROWTH $1 \mathrm{~N} 6.5 \% \mathrm{NaCI}$ & NC6.5 & + \\
\hline 52 & D-MANNITOL & dMAN & - \\
\hline 53 & D-MANNOSE & dMNE & - \\
\hline 54 & METHYL-B-D-GLUCOPYRANOSIDE & MBdG & - \\
\hline 56 & PULLULAN & PUL & - \\
\hline 57 & D-RAFFINOSE & dRAF & - \\
\hline 58 & O/129 RESISTANCE (comp.vibrio.) & o129R & + \\
\hline 59 & SALICIN & SAL & - \\
\hline 60 & SACCHAROSE/SUCROSE & SAC & + \\
\hline 62 & D-TREHALOSE & dTRE & - \\
\hline 63 & ARGININE DIHYDROLASE 2 & $\mathrm{ADH} 2 \mathrm{~s}$ & - \\
\hline 64 & OPTOCHIN RESISTANCE & OPTO & + \\
\hline
\end{tabular}


Another two Gram positive isolates were identified biochemically by VITEK2 system as Bacillus cereuswith85 \% probability. Analysis time was 14.25 hours; the biochemical details of Bacillus cereus isolates are mentioned in (Table 2). Only one gram negative isolates was identified by VITEK2 system as Pseudomonas stutzeri, with91 \% probability; analysis time was 10.25 hours. The biochemical details are mentioned in (Table 3).

Table 2: Biochemical characters of Bacillus cereus identified by VITEK 2 system, isolated from Dicentrarchus labrax.

\begin{tabular}{|c|c|c|c|}
\hline Well N. & Biochemical reaction & Appreciation & Results \\
\hline 1 & BETA-XYLOSIDASE & BXYL & - \\
\hline 3 & L-Lysine-ARYLAMIDASE & LysA & - \\
\hline 4 & L-Aspartate ARYLAMIDASE & AspA & - \\
\hline 5 & LeucineARYLAMIDASE & LeuA & + \\
\hline 7 & Phenylalanine ARYLAMIDASE & PheA & - \\
\hline 8 & L-Proline ARYLAMIDASE & ProA & - \\
\hline 9 & BETA-GALACTOSIDASE & BGAL & - \\
\hline 10 & L-Pyrrolidonyl-ARYLAMIDAS E & PyrA & + \\
\hline 11 & ALPHA.GALACTOSIDASE & AGAL & - \\
\hline 12 & Alanine ARYLAMIDASE & AlaA & - \\
\hline 13 & Tyrosine ARYLAMIDASE & TyrA & - \\
\hline 14 & BETA-N-AC ETYL-GLUCOSAMINIDASE & BNAG & - \\
\hline 15 & Ala-Phe-Pro ARYLAMIDASE & APPA & + \\
\hline 18 & CYCLODEXTRINE & CDEX & - \\
\hline 19 & D-GALACTOSE & dGAL & - \\
\hline 21 & GLYCOGENE & GLYG & - \\
\hline 22 & myo-INOSITOL & INO & - \\
\hline 24 & METHYL-A-D-GLUCOPYRANOSIDEacidification & MdG & - \\
\hline 25 & ELLMAN & ELLM & - \\
\hline 26 & METHYL-D-XYLOSIDE & $\mathrm{MdX}$ & - \\
\hline 27 & ALPHA.MANNOSIDASE & AMAN & - \\
\hline 29 & MALTOTRIOSE & MTE & + \\
\hline 30 & Glycine ARYLAMIDASE & GlyA & - \\
\hline 31 & D-MANNITOL & dMAN & - \\
\hline 32 & D-MANNOSE & $\mathrm{dMNE}$ & - \\
\hline 34 & D-MELEZITOSE & dMLZ & - \\
\hline 36 & N-ACETYL-D-GLUCOSAMI N E & NAG & + \\
\hline 37 & PALATINOSE & PLE & - \\
\hline 39 & L-RHAMNOSE & IRHA & - \\
\hline 41 & BETA-GLUCOSIDASE & BGLU & - \\
\hline 43 & BETA-MANNOSIDASE & BMAN & - \\
\hline 44 & PHOSPHORYL CHOLINE & PHC & - \\
\hline 45 & PYRUVATE & PVATE & + \\
\hline 46 & ALPHA.GLUCOSIDASE & AGLU & + \\
\hline 47 & D-TAGATOSE & dTAG & - \\
\hline 48 & D-TREHALOSE & dTRE & - \\
\hline 50 & INULIN & INU & - \\
\hline 53 & D-GLUCOSE & dGLU & + \\
\hline 54 & D-RIBOSE & $\mathrm{dRIB}$ & + \\
\hline 56 & PUTRESCINE assimilation & $\mathrm{PSCNa}$ & - \\
\hline 58 & GROWTH IN 6.5\% NaCl & $\mathrm{NaCI} 6.5 \%$ & + \\
\hline 59 & KANAMYCIN RESISTANCE & KAN & + \\
\hline 60 & OLEANDOMYCIN RESISTANCE & OLD & - \\
\hline 61 & ESCULIN hydrolyse & ESC & + \\
\hline 62 & TETRAZOLIUM RED & TTZ & - \\
\hline 63 & POLYMYXIN B RESISTANCE & POLYB_R & + \\
\hline
\end{tabular}


Table 3: Biochemical characters of Pseudomonas stutzeri identified by VITEK 2 system, isolated from Dicentrarchus labrax.

\begin{tabular}{|c|c|c|c|}
\hline Well N. & Biochemical reaction & Appreciation & Results \\
\hline 2 & Ala-Phe-Pro-ARYLAMIDASE & APPA & - \\
\hline 3 & ADONITOL & $\mathrm{ADO}$ & - \\
\hline 4 & L- Pyrrolydonyl-ARYLAMIDASE & PyrA & - \\
\hline 5 & L-ARABITOL & IARL & - \\
\hline 7 & D-CELLOBIOSE & $\mathrm{dCEL}$ & - \\
\hline 9 & BETA-GALACTOSIDASE & BGAL & - \\
\hline 10 & H2S PRODUCTION & $\mathrm{H} 25$ & - \\
\hline 11 & BETA-N-ACETYL-GLUCOSAMINIDASE & BNAG & - \\
\hline 12 & GlutamylArylamidasepNA & AGLTP & - \\
\hline 13 & D-GLUCOSE & dGLU & + \\
\hline 14 & GAMMA-GLUTAMYL-TRANSFE RASE & GGT & - \\
\hline 15 & FERMENTATION/ GLUCOSE & OFF & - \\
\hline 17 & BETA-GLUCOSIDASE & BGLU & - \\
\hline 18 & D-MALTOSt & dMAL & + \\
\hline 19 & D-MANNITOL & dMAN & + \\
\hline 20 & D-MANNOSE & dMNE & - \\
\hline 21 & BETA-XYLOSIDASE & BXYL & - \\
\hline 22 & BETA-Alanine arylamidasepNA & BAlap & - \\
\hline 23 & L-Proline ARYLAMIDASE & ProA & + \\
\hline 26 & LIPASE & LIP & - \\
\hline 27 & PALATINOSE & PLE & - \\
\hline 29 & Tyrosine ARYLAMIDASE & TyrA & + \\
\hline 31 & UREASE & URE & - \\
\hline 32 & D-SORBITOL & $\mathrm{dSOR}$ & - \\
\hline 33 & SACCHAROSE/SUCROSE & SAC & - \\
\hline 34 & D-TAGATOSE & dTAG & - \\
\hline 35 & D-TREHALOSE & dTRE & - \\
\hline 36 & CITRATE(SODTUM) & CIT & + \\
\hline 37 & MALONATE & MNT & + \\
\hline 39 & 5-KETO-D-GLUCONATE & $5 \mathrm{KG}$ & - \\
\hline 40 & L-LACTATE alkalinization & ILATK & + \\
\hline 41 & ALPHA-GLUCOSIDASE & AGLU & - \\
\hline 42 & SUCCINATE alkalinization & SUCT & + \\
\hline 43 & Beta-N-ACETYL-GALACTOSAMINIDASE & NAGA & - \\
\hline 44 & ALPHA-GALACTOSIDASE & AGAL & - \\
\hline 45 & PHOSPHATASE & PHOS & - \\
\hline 46 & Glycine ARYLAMIDASE & GIyA & - \\
\hline 47 & ORNITHINE DECARBOXYLASE & ODC & - \\
\hline 48 & LYSINE DECARBOXYLASE & LDC & - \\
\hline 52 & DECARBOXYLASE BASE & ODEC & - \\
\hline 53 & L-HISTIDINE assimilation & IHISa & + \\
\hline 56 & COURMARATE & CMT & - \\
\hline 57 & BETA-GLUCURONIDASE & BGUR & - \\
\hline 58 & O/129 RESISTANCE (comp.vibrio.) & o129R & - \\
\hline 59 & Glu-Gly-Arg-ARYLAMIDASE & GGAA & - \\
\hline 61 & L-MALATE assimilation & IMLTA & - \\
\hline 62 & ELLMAN & ELLM & + \\
\hline 64 & L-LACTATE assimilation & ILATA & - \\
\hline
\end{tabular}

Two Staphylococcus epidermidis isolates were recovered from internal organs of systemically affected fish. From topical lesions other five isolates (two Staphylococcus epidermidis, two Bacillus cereus and one Pseudomonas stutzeri) were isolated from swabs taken from skin, tail and musculature (Table 4). To the best of our knowledge edge, there is no any report for isolation of Staphylococcus 
epidermidis, Bacillus cereus and Pseudomonas stutzeri from diseased European sea bass (Dicentrarchus labrax) in Egypt and this article is considered the first report documented the presence of these isolates.

Table 4: Identified bacteria from internal organs and topical lesions of Dicentrarchus labrax.

\begin{tabular}{|l|c|c|}
\hline Bacterial Isolates & From internal organs & From topical lesions \\
\hline Staphylococcus epidermidis & 2 & 2 \\
\hline Bacillus cereus & - & 2 \\
\hline Pseudomonas stutzeri & - & 1 \\
\hline
\end{tabular}

Brood stock fish during spawning season are suffered from variety of stress factors including continuous handling and excessive gonads production, which may affect its immune status negatively, inducing immunosuppression that subsequently make it more susceptible to pathogens. Furthermore, continuous handling may induce skin abrasions and lacerations that consider a portal of entry of pathogenic bacteria. Some of these bacteria can induce systemic disease after replication and propagation in local lesions (as skin and musclulature) and this can be an explanation for systemic infection with Staphylococcus epidermidis. Moreover, Staphylococcus epidermidis was isolated from a variety of diseased fresh and marine fished causing systemic infection as recorded by Kusuda and Sugiyama (1981), Yiagnisis and Athanassopoulou, (2011) and Varvarigos, (2016). Bacillus cereus and Pseudomonas stutzeriare considered environmental bacteria (not considered a potential pathogen but cause disease in immunosuppressed host) more than obligate pathogen, although others, including Goodwin et al. (1994), Chandra et al. (2015) and Sariati et al. (2015) recorded their isolation from systemically affected fish. The present results revealed the presence of this two species only in local lesions (skin, musculature and tail) and this does not decrease their role in the disease occurrence, but to give best understanding to current research results, and to overcome this argue about their role and potency to induce such disease, further detailed studied are needed.

\section{CONCLUSIONS}

In conclusion Staphylococcus epidermidis, Bacillus cereus and Pseudomonas stutzeri were isolated from diseased European sea bass (Dicentrarchus labrax) for the first time in Egypt. They are considered the main causative agents. Further studies are needed to determine their virulence factors and disease pathogenesis.

\section{ACKNOWLEDGEMENT}

The authors would like to thank Prof. Dr. Amal F. A. Fayez, Fish Reproduction Lab, Aquaculture Division, National Institute of Oceanography and Fishery (NIOF), Egypt.

\section{REFERENCES}

Aboyadak, I. (2016). Standard method for experimental infection \& treatment of Nile Tilapia. First Edition, LAP LAMBERT Academic Publishing, BahnhofstraBe 28, 66111 Saarbrucken, Deutschland / Germany.

Anderson, J. and Conroy, D. (1970).Vibrio Disease in Marine Fishes. In: A Symposium in Marine Fishes and Shellfishes. Snieszko, F.F. (Ed.), Special Publication No. 5, American Fisheries Society, USA. 
Austin, B. and Austin, D. A. (2012). Bacterial Fish Pathogens Disease of Farmed and Wild Fish. $5^{\text {th }}$ Edition, Springer Praxis, Chichester, pp. 115, ISBN 978-94-0074883-5.

Buller, N. B. (2004). Bacteria from fish and other aquatic animals, A practical identification manual. CABI Publishing, UK.

Chandra, G;Bhattacharjee, I. and Chatterjee, S. (2015). Bacillus cereus infection in stinging catfish, Heteropneustesfossilis (Siluriformes: Heteropneustidae) and their recovery by Argemonemexicana seed extract. Iranian Journal of Fisheries Sciences, 14(3): 741-753.

Collins, C. H; Lyne, P. M; Grnge, J. M. and Falkinham, J. O. (2004). Collins and Lyne's Microbiological methods 8th edition, Arnold, a member of the Hodder Headling group London U. K.

GAFRD, General Authority for Fish Resources (2016).Fish Statistics yearbook 2014, General Authority for Fish Resources, Egypt.

Goodwin, A. E; Roy, J. S; Grizzle, J. M. and Goldsby, M. T. (1994).Bacillus mycoides: a bacterial pathogen of channel catfish Diseases of Aquatic Organisms, 18: 173-179

Heil, N. (2009). National wild fish health survey- laboratory procedures manual, fifth edition. U. S. fish and wildlife service, Warm springs, GA.

Huang, S; Chen, W;Shei, M; Liao, I. and Chen, S. (1999). Studies on epizootiology and pathogenicity of Staphylococcus epidermidis in Tilapia (Oreochromis spp.) cultured in Taiwan. Zoological Studies, 38:178-188.

Kusuda, R. and Sugiyama A. (1981). Studies on the characters of Staphylococcus epidermidis isolated from diseased fishes. Part 1. On the morphological, biological and biochemical properties. Fish Pathology, 16:15-24.

Noga, E. J. (2010). Fish Disease Diagnosis and Treatment. $2^{\text {nd }}$ Edition, Blackwell Publishing, U.S.A.

PHE, Public Health England (2015). Identification of Bacillus species. UK Standards for Microbiology Investigations. ID 9 Issue 3. https://www.gov.uk/ukstandards-for-microbiology-investigations-smi-quality-and-consistency-inclinical-laboratories

Sariati, W. N. E; Kurniasih, S. A. and Widayanti, R. (2015). Phenotypic and Genotypic Comparison of Pseudomonas stutzeriin Freshwater Fish in Indonesia. Journal of Agricultural Science and Technology, B( 5): 292-296. doi: 10.17265/2161-6264/2015.04.008.

Toranzo, A. E; Magariños, B. and Romalde, J. L. (2005). A review of the main bacterial fish diseases in mariculture systems. Aquaculture, 246(1-4):37-61.

Varvarigos, P. (2016). Gram positive coccobacteria (Micrococcaceae, Streptococcaceae) causing systemic disease to intensively farmed marine fish in the Mediterranean. A brief review. [online] http://www.vetcare.gr/ARTPRES/Gram_positive_cocci.htm

Vázquez, F. J. S. and Muñoz-Cueto, J. A. (2015). Biology of European Sea Bass. CRC Press, Taylor \& Francis Group, 6000 Broken Sound Parkway NW, Suite 300, Boca Raton, FL 33487-2742. ISBN-13: 978-1-4665-9946-8

Yiagnisis, M. and Athanassopoulou, F. (2011). Bacteria Isolated from Diseased Wild and Farmed Marine Fish in Greece, Recent Advances in Fish Farms, Aral, F. (Ed.), ISBN: 978-953-307-759-8, InTech Europe, University Campus STePRi, SlavkaKrautzeka 83/A, 51000 Rijeka, Croatia. 


\section{Plate A}

\begin{tabular}{|c|c|}
\hline $\mathbf{1}$ & $\begin{array}{l}\text { Naturally infected European sea bass (Dicentrarchus labrax) showing scale } \\
\text { desquamation and skin ulceration (arrow). }\end{array}$ \\
\hline $\mathbf{2}$ & $\begin{array}{c}\text { Naturally infected European sea bass (Dicentrarchus labrax) with multiple } \\
\text { hemorrhagic spots in ventral surface and hemorrhagic eroded pelvic fin. }\end{array}$ \\
\hline $\mathbf{3}$ & $\begin{array}{l}\text { Naturally infected European sea bass (Dicentrarchus labrax) with severely eroded } \\
\text { hemorrhagic tail. }\end{array}$ \\
\hline $\mathbf{4}$ & $\begin{array}{c}\text { Naturally infected European sea bass (Dicentrarchus labrax) with enlarged } \\
\text { congested liver with presence of hemorrhagic foci. }\end{array}$ \\
\hline $\mathbf{5}$ & Staphylococcus epidermidis grown on Rimler-Shottsmedia giving green colonies. \\
\hline
\end{tabular}

\section{Plate B}

\begin{tabular}{|c|c|}
\hline $\mathbf{1}$ & $\begin{array}{c}\text { Pin headed size white colony of Staphylococcus epidermidis grown on Tryptic soy } \\
\text { agar. }\end{array}$ \\
\hline $\mathbf{2}$ & $\begin{array}{c}\text { Large white spherical colonies with dull surface and undulate margins (4 }-5 \mathrm{~mm} \\
\text { in diameter) of Bacillus cereus grown on Tryptic soy agar. }\end{array}$ \\
\hline $\mathbf{3}$ & $\begin{array}{c}\text { Rounded creamy colonies (2 - } 3 \mathrm{~mm} \text { in diameter) of Pseudomonas stutzeri grown } \\
\text { on Tryptic soy agar. }\end{array}$ \\
\hline $\mathbf{4}$ & $\begin{array}{c}\text { Staphylococcus epidermidis, gram positive cocci present as single, pairs, short } \\
\text { chain and irregular clusters (oil immersion lens, } \mathrm{X}=1000) .\end{array}$ \\
\hline $\mathbf{5}$ & $\begin{array}{c}\text { Bacillus cereus, gram positive long bacilli present single, pairs, and chains, has } \\
\text { centrally located endospore (oil immersion lens, } \mathrm{X}=1000) .\end{array}$ \\
\hline $\mathbf{6}$ & $\begin{array}{c}\text { Pseudomonas stutzeri, gram negative short bacilli present single or in pairs (oil } \\
\text { immersion lens, } X=1000) .\end{array}$ \\
\hline
\end{tabular}




\section{Plate A}
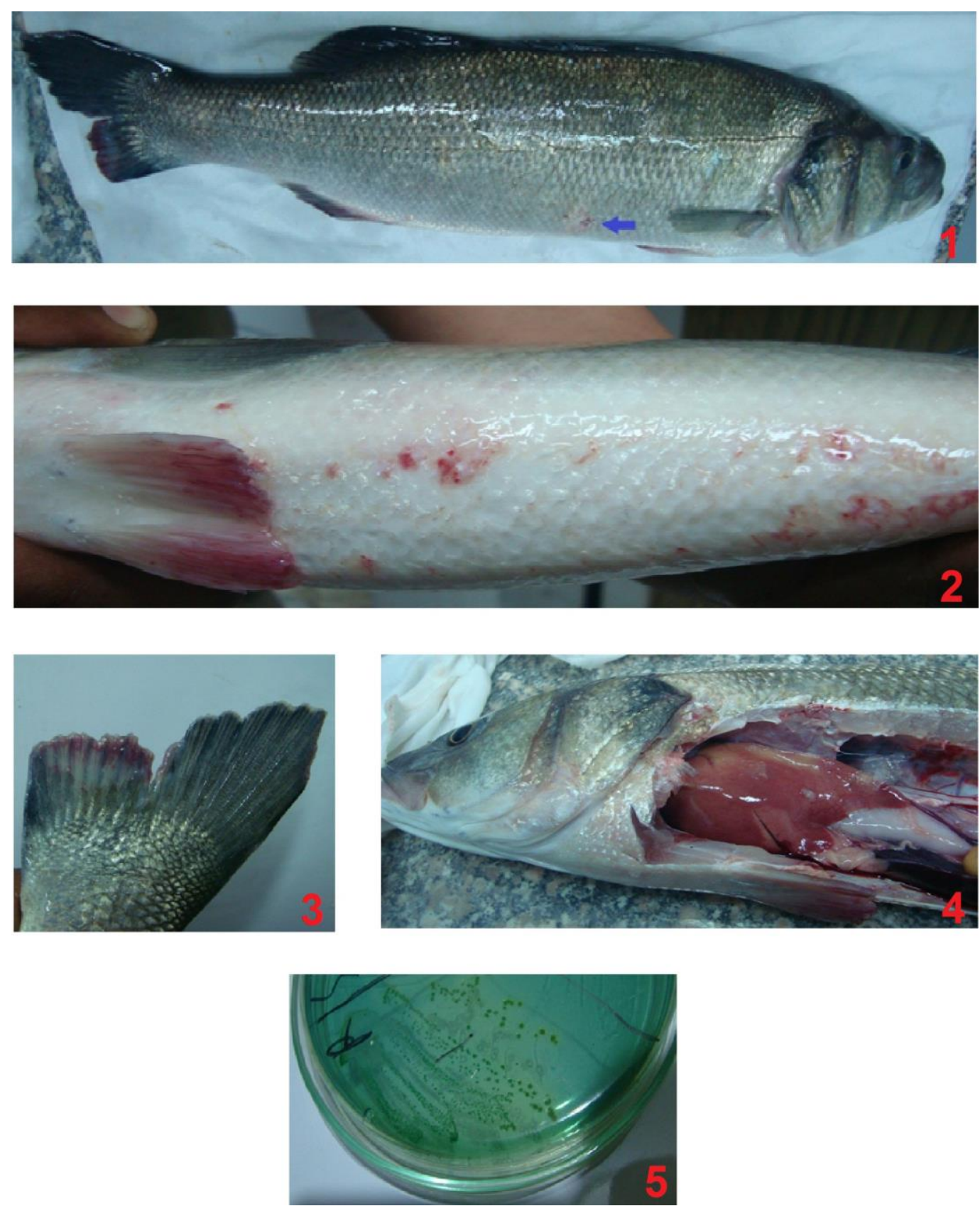

1- Naturally infected European sea bass (Dicentrarchus labrax) showing scale desquamation and skin ulceration (arrow).

2- Naturally infected European sea bass (Dicentrarchus labrax) with multiple hemorrhagic spots in ventral surface and hemorrhagic eroded pelvic fin.

3- Naturally infected European sea bass (Dicentrarchus labrax) with severely eroded hemorrhagic tail.

4- Naturally infected European sea bass (Dicentrarchus labrax) with enlarged congested liver with presence of hemorrhagic foci.

5- Staphylococcus epidermidis grown on Rimler-Shottsmedia giving green colonies. 


\section{Plate B}
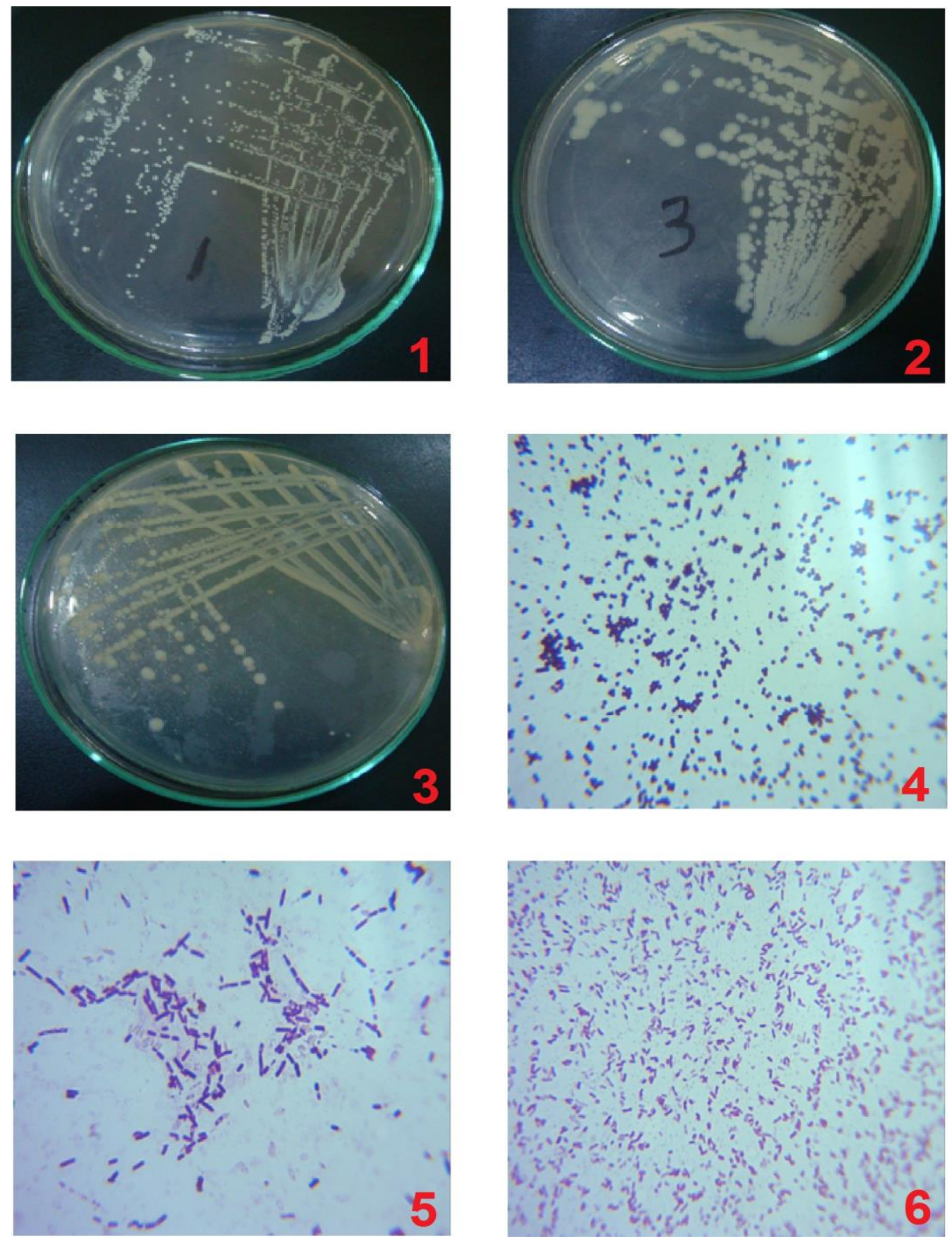

1- Pin headed size white colony of Staphylococcus epidermidis grown on Tryptic soy agar.

2- Large white spherical colonies with dull surface and undulate margins (4-5 $\mathrm{mm}$ in diameter) of Bacillus cereus grown on Tryptic soy agar.

3- Rounded creamy colonies (2 - $3 \mathrm{~mm}$ in diameter) of Pseudomonas stutzeri grown on Tryptic soy agar.

4- Staphylococcus epidermidis, gram positive cocci present as single, pairs, short chain and irregular clusters (oil immersion lens, $\mathrm{X}=1000$ ).

5- Bacillus cereus, gram positive long bacilli present single, pairs, and chains, has centrally located endospore (oil immersion lens, $\mathrm{X}=1000$ ).

6- Pseudomonas stutzeri, gram negative short bacilli present single or in pairs (oil immersion lens, $X=1000$ ). 


\section{ARABIC SUMMARY}

عزل بعض انواع من البكتريا الممرضة لسمكة القاروص الاوروبي لأول مرة في مصر.

ابراهيم ابويدك, ${ }^{1}$ نادر صبري 1, نادية علي, $1{ }^{1}{ }^{1}{ }^{2}{ }^{2}$

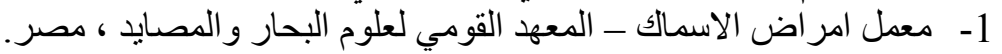

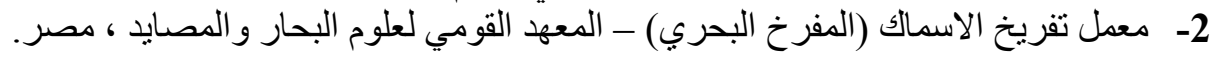

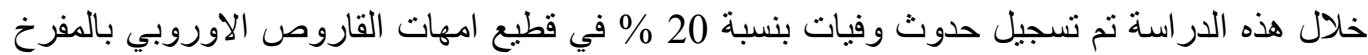

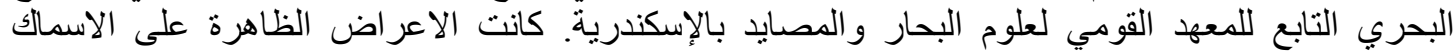

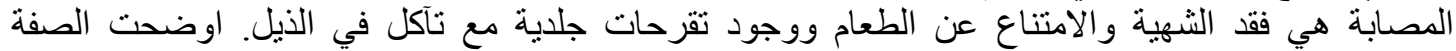

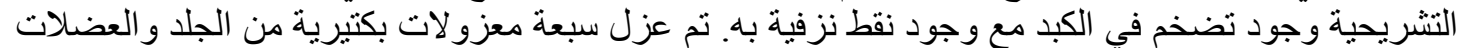

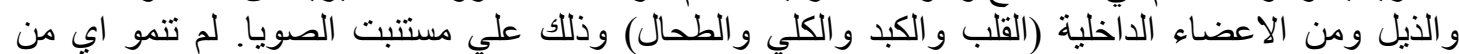

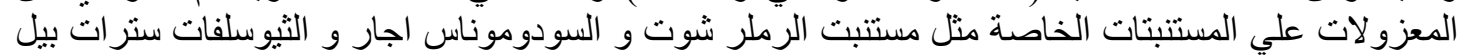

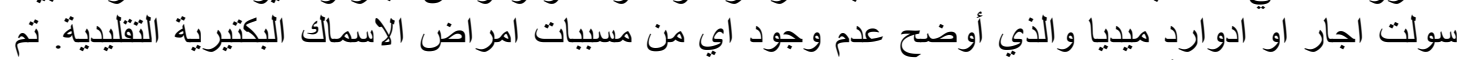

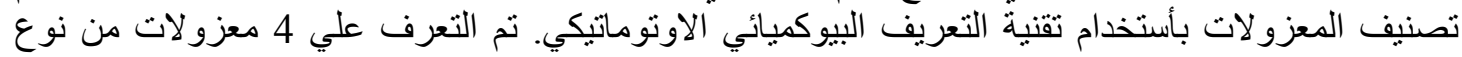

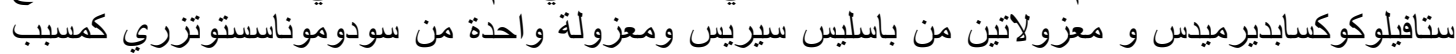

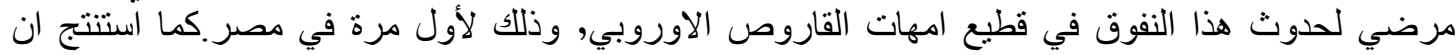
الاجهاد الحادث اثناء عملية التفريخ يعد من العو امل الممهدة لحدوث هذا لأندا النفوق. 